\title{
HOW VARIOUS METHODS OF WINTERING AFFECT PASTURE SWARDS
}

J. ADAM, Hamilton Farm Improvement Club, Hamilton

Nowadays it is fashionable to emphasise how skilful and knowledgeable the farmer has to be. It is said that he has to be a botanist, chemist, engineer, carpenter, stockbreeder, and a competent accountant. A combination of all the qualifications held by these experts might sound very desirable, but they are not at all necessary to make a good farmer. He can hire the services of a trained technical officer from a competent firm selling herbicides and insecticides, employ the local blacksmith and a carpenter, and take the advice of his bank manager and accountant on financial matters. One quality, however, he cannot buy or hire is managerial skill which will enable him to feed his cows efficiently over 365 days a year without doing damage to his pasture and his pocket.

Efficient farmers have been taking more and more notice of the results from controlled experiments at Ruakura Animal Research Station showing that a high stocking rate is the key to high production (1 ) per acre. Unfortunately with a higher stocking rate a certain amount of damage can be caused to the sward during the winter which will cut down the growth during spring and summer and, in extreme cases, slow down the growth for 12 months or longer. In a survey of German grasslands it was found that the weight of roots increased with increasing pore space in the soil (2). At last year's conference D. B. Edmond concluded that the effects of animal treading must be carefully considered wherever animals graze pasture (3). In many cases heavy pugging and changes of the pore space in the first 3 in. of the soil will cut down the oxygen supply to the roots, a deficiency which cannot be overcome by heavy LPK applications. Although numerous methods of grazing and spelling a pasture in the winter have been used with varied success to overcome damage caused by the hoof of the animal, only three will be discussed in this paper.

1. Holding paddock in combination with autumn-saved pasture (A.S.P.).

2. Loafing barn and self feeding silage.

3. Grass alone.

\section{H olding P addock}

A very popular method used mainly among farmers who are growing a summer or winter crop is the use of a holding paddock or, as it is sometimes called, a sacrifice paddock where cows are kept before calving down. As the name indicates the sward is 
Q. (Dr L. R. Wallace): I congratulate the executive on bringing the problem of winter wet soils before the conference and $\mathrm{Mr}$ Jordan likewise. feel this is one of the most important problems worthy of an expanded programme of research. What are the conditions under which cows are lying after calving? What do they lie on and are there any troubles, feet and so on?

A. So long as the race is crowned sufficiently there is no trouble from slush. The races are relatively short. Cows have to lie on the same area they walk on, but they are lying on relatively dry ground. If they did lie down in slush it was not normal. Mastitis did not increase. In the covered shed, cows preferred to lie on the concrete where there was no litter. The shed was cleaned by a blade or a squeegee type cleaner one or two times a season.

Q. (Dr L. R. Wallace): How long would the cows be off the concrete?

A. Two to three hours each day but they could exercise down the race. Overseas they wouldn't think of it.

Comment (Mr E. H. Arnold): I congratulate Mr Jordan on his paper, and his introduction of these practices to the Northern Wairoa Flats. I would like to comment on the history of run-offs. Some 30 years ago bafore motor transport was used by farmers, stock were taken off the flats and placed on adjacent hill country run-offs. Here they existed or starved over the winter on fern and short tea-tree and rain bleached grasses. Later farmers were persuaded to cart hay from the good areas on the flat and feed it to the cattle on the run-offs during the winter. Gradually the fern and scrub were reduced, and pastures were improved by seed from the hay and topdressing. Occasionally areas of the run-offs were cultivated and sown down. As feed conditions improved, sharemilkers were established on these areas. The farmer who milks on the two properties now has to look further afield for another run-off and this is more distant from the home farm, is of lower fertility, more rugged, and produces less and poorer food. 
sacrificed by continuous pugging, caused not only by the cows but also by tractor and trailer wheels when hay or silage is fed out. Where no crops are required, pasture improvements in the form of under- or oversowing are sometimes carried out. Generally a satisfactory germination takes place by undersowing a holding paddock with a seed mixture of $12 \mathrm{lb}$ per acre. However, as the soil structure has been destroyed during the winter, the young seedlings do not thrive and the rate of growth is considerably restricted. Over-sowing after a light surface cultivation to level the paddock and allow air penetration into the top 3 in. might show a high weed population. This can be easily rectified by spraying the paddock with one of the butyrics. A third practice of just leaving the paddock and letting Nature do the trick will grow some kind of pasture later in the year. The pasture so produced cannot compare with the feed produced by modern strains of grasses and clovers.

A.S.P. is often grazed in conjunction with a holding paddock by using the "on-and-off" system. This system allows cows to graze a restricted area of pasture during a specified period, after which they are put back into the holding paddock. Two factors have to be considered when A.S.P. is grazed under this system.

(a) Status of fertility.

(b) Height of grass.

(a) On medium and low fertility soils the removal of nutriments has to be counteracted by using the paddock as a night paddock during the following season. Adequate applications of muriate of potash and superphosphate should also be made to replace the loss of potassium and phosphorus. Where this practice is adopted no changes in the pasture composition due to lack of fertility will occur.

(b) Height of grass: The height of the sward is the most critical factor when the aftermath or second round is discussed. It is not the purpose of this paper to recommend the time or stage when a paddock should be shut up for autumn-saved pasture. It can, however, be stated as far as the quality, composition, and vigour of the second round are concerned, that the shorter the autumnsaved pasture is the better will the regrowth be. Long grass not only inhibits the process of tillering but also causes bare patches and weed infestation, whereas shorter pastures grazed off will recover more rapidly and will form a dense sward.

\section{Loafing Barns}

The introduction of loafing barns or wintering sheds would appear to be an easy way of overcoming excessive pugging and, as far as the farmer himself is concerned, the hard slogging of 
feeding out. This practice of keeping cows under cover goes back to the times when cows were converted into domestic animals, especially in countries whose climate does not allow grazing during the winter. Then all dung and urine were collected, properly composted, and put back on to the land. Without the return of this material the majority of farms in Europe would have turned into barren ground.

Loafing barns in this country were developed primarily to overcome excessive pugging and damage to the, pasture, and by their use considerable production increases are known to have been achieved. On the other hand these increases may have been achieved at the expense of the overall fertility of the farm. Where hay or silage is cut from the same paddock every year and not fed out on them a very weak sward will develop and will later turn into second-rate pasture. Therefore it is of the utmost importance to collect all the droppings and urine while animals are fed in a barn and return them regularly to the paddock by a muck spreader. This practice should also be used where cows are kept in a small paddock and self feeding of silage is practised.

\section{Grass Alone}

The third method is the practice of feeding out silage during the last two months of the lactation and relying on grass during the winter. L. R. Wallace at the 1958 Ruakura Conference said that A.S.P. provided on an increasing number of farms the main or even the sole feed for the herd for some six or eight weeks about the time of calving. He added that with the many ingenious semipermanent electric fencing systems now available these saved pastures could be fed off most efficiently with the minimum of labour (4).

Applying this principle, members of the Hamilton Farm Improvement Club have developed a method by which they aimed at feeding their cows properly before calving and at the same time doing as little damage as possible to the existing sward. The method has been used with equal success on Horotiu sandy loam and Hamilton clay loam.

The management for a herd of 100 cows on a cow-to-the-acre farm is as follows: With the onset' of the autumn rains, usually round 15 March in the Waikato, 30 acres will be shut up. The grass intake of the milking herd will be restricted and silage will be fed out. Further paddocks for the use of the milkers will be shut up during the second half of April and May, and all cows will be dried off on 10 May and used for cleaning up gullies and rough corners. From 1 June all dry cows will be break-fed on one acre per 24 hours, using the area which was shut up on 15 
April and which by now will have grown to a considerable height. Every acre will be backfenced regardless of water, as the moisture in the herbage is enough to satisfy the cows' need. This can be seen from the following simple method of estimating the weight of pastures which might be useful to farmers. A square plot of $3 \mathrm{ft}$ by $3 \mathrm{ft}$ of the average pasture has to be cut and weighed. By multiplying this weight by two an approximate yield in tons per acre is obtained. Thus if a pasture yields $5 \mathrm{lb}$ of green weight from the average square yard, the yield is approximately 10 tons per acre. A ryegrass-white clover pasture when 10 to 12 in. high will yield about 10 tons per acre of green weight. The dry matter content of A.S.P. will be round 20 per cent, which means that 10 tons of green weight will supply two tons of dry matter and eight tons of moisture. This is equivalent to $44.8 \mathrm{lb}$ of dry matter and $179 \mathrm{lb}$ of water per cow for. 24 hours, a more than adequate ration for a dry cow.

Experience has shown that by using this method no damage is caused by treading or pugging. After a few days cows are getting used to this method and do not spend all day wandering around looking for feed. The quick grazing of A.S.P. at this stage helps in stooling it out and recovery is rapid. After 24 hours on the break the cows have distributed their dung fairly evenly. Paddocks grazed with dry cows in the first week in June can be grazed with the milkers during the first week in August. The palatability of the sward is generally very high and observation has shown that the cows' milking capacity is at its maximum.

The advantage of the described method can be clearly seen on a farm where silage was fed out on a six acre paddock from 15 May to 1 June. Although this holding paddock was not turned into a sacrifice paddock, it was far from ready to be grazed with the milkers in August, and nine months later poa annua and flat weed infestation showed the effects of continuous treading, whereas paddocks grazed on the 24 hour system were in excellent condition.

\section{Conclusion}

The composition and vigour of a pasture sward after wintering will be determined by the behaviour of the three seemingly independent parts of a cow's body; her mouth, her hoof, and her tail:

Her mouth, which enables her to over- or undergraze the sward. Her hoof, which will encourage or destroy the root system.

Her tail, which lifts to put back the fertility into the right place.

The correct correlation of these three factors will be determined by the managerial ability of the farmer himself. 